\title{
Anthropometric differences in the newborns with brachial plexus palsy, clavicle fracture in pregnancies without risk factor
}

\author{
Hüseyin Kıyak ${ }^{1}$ (D) , Alev Atış Aydın² (iD), Gökhan Bolluk² (D) , Emel Canaz ${ }^{3}$ (D) , \\ Zemzem Ulaşkın' ${ }^{1}$ iD , Ali Gedikbaşı ${ }^{2}$ \\ ${ }^{\prime}$ Gynecology and Obstetrics Clinic, İstanbul Kanuni Sultan Siileyman Training and Research Hospital, İstanbul, Turkey \\ ${ }^{2}$ Gynecology and Obstetrics Clinic, Perinatology Department, İstanbul Kanuni Sultan Sïleyman Training and Research Hospital, İstanbul, Turkey \\ ${ }^{3}$ Department of Obstetrics and Gynecology, Faculty of Medicine, İstanbul Bilim University, İstanbul, Turkey
}

\begin{abstract}
Objective: To make predictions for antenatal evaluation by using anthropometric data of the newborns which undergo the complications of brachial plexus palsy, clavicle fracture and shoulder/humerus fracture in cases with low risk in terms of shoulder dystocia.

Methods: After the risk factors that may cause deliveries with dystocia such as fetal macrosomia, maternal diabetes, maternal obesity and excessive weight gain during pregnancy, history of shoulder dystocia, labor induction and epidural anesthesia were ruled out, birth complication cases found in the hospital database retrospectively were matched one by one with data of the newborns which had same obstetric and demographic characteristics, same weights and genders but did not undergo labor trauma.

Results: A total of 185 newborn complications were observed, and of these complications, 149 were classified as clavicle fracture, 8 as shoulder and humerus fracture, and 28 as brachial plexus palsy. It was seen that the 2 nd stage of labor was significantly longer in the cases which underwent birth complication ( $\mathrm{p}=0.01 ; 22.41 \pm 6.98$ minutes vs. $24.23 \pm 6.43$ minutes). Shoulder dystocia was more frequent in the study group which had complications ( $\mathrm{p}=0.0001 ; 32.97 \%$ vs. $2.7 \%$ ). In terms of anthropometric measurements, the ROC analysis of thorax circumference / head circumference ratio was significant, and it was seen that shoulder dystocia and the complications could be predicted in case that the ratio is higher than 0.97 ( $\mathrm{AUC}=0.903$; sensitivity $77.84 \%$, specificity $89.73 \%$, PPV $88.3 \%$, NPV $80.2 \%$, LR 7.58 ). It was found that the rate of complications increased significantly in cases which were above $4000 \mathrm{~g}(\mathrm{p}=0.029)$.

Conclusion: Shoulders and its extensions are vulnerable to trauma within birth canal. In our hypothesis, neonatal anthropometric data were significantly correlated with the complications. In order to make a prediction, bisacromial diameter and thorax circumference measurements as well as fetal head measurements may be helpful during antenatal period and labor in particular.
\end{abstract}

Keywords: Newborn anthropometric measurements, shoulder dystocia, labor trauma.
Özet: Risk faktörü olmayan gebeliklerde brakiyal pleksus felci ve klavikula kırığı olgularında yenidoğanda antropometrik farklılıklar

Amaç: Omuz distosisi açısından düşük risk taşıyan olgularda brakiyal pleksus felci, klavikula kırığı ve omuz/humerus kırı̆g 1 komplikasyonlarını yaşayan yenidoğanların antropometrik verilerinden yararlanarak antenatal değerlendirmeye yönelik öngörü oluşturmak.

Yöntem: Distosik doğuma neden olabilecek fetal makrozomi, maternal diyabet, maternal obezite ve gebelikte aşırı kilo alımı, omuz distosisi öyküsü, doğum indüksiyonu, epidural anestezi gibi risk faktörleri dışlandıktan sonra hastane veri tabanından retrospektif olarak çıkarılan doğum komplikasyonu olguları, aynı obstetrik ve demografik özellikleri taşıyan, ancak doğum travması yaşamayan, aynı tartı ve cinsiyette yenidoğan verileri ile birebir eşleştirildi.

Bulgular: 185 yenidoğan komplikasyonu gözlendi; bunların 149 tanesi klavikula kırığı, 8 tanesi omuz ve humerus kırı̆̆ı, 28 tanesi de brakiyal pleksus felci olarak sinıflandırıldı. Doğum komplikasyonu yaşanan olgularda doğumun 2. evresinin anlamlı şekilde daha uzun olduğu görüldü $(\mathrm{p}=0.01 ; 22.41 \pm 6.98$ dakikaya karşıllı $24.23 \pm 6.43$ dakika). Omuz distosisi, komplikasyonların yaşandığı çalıșma grubunda daha sık gözlendi ( $\mathrm{p}=0.0001$; sıklığ1 \% 32.97'ye karşılık \%2.7). Antropometrik ölçümler açısından göğüs çevresi / baş çevresi oranlarının ROC çalışması anlamlı saptandı, oranın 0.97'den büyük olmas1 durumunda (AUC $=0.903$; sensitivite $\% 77.84$, spesifisite \%89.73, PPD \%88.3, NPD \%80.2, LR 7.58) omuz distosisi ve komplikasyonları öngörebileceği görüldü. Komplikasyonların 4000 gramın üstündeki olgularda anlamlı olarak artmaya başladığı saptan$\mathrm{d}_{1}(\mathrm{p}=0.029)$.

Sonuç: Doğum kanalı içinde omuzlar ve uzantıları travmaya açıtır. İleri sürdüğümüz hipotezde neonatal antropometrik veriler komplikasyonlar ile anlamlı şekilde korele bulunmuştur. Bir öngörüde bulunmak için, antenatal dönem ve özellikle de eylem sırasında fetal baş ölçümlerinin yanı sıra ayrıca bisakromiyal çap ve göğüs çevresi ölçümleri yardımcı olabilir.

Anahtar sözcükler: Yenidoğan antropometrik ölçümleri, omuz distosisi, doğum travması.

Correspondence: Ali Gedikbaşı, MD. Gynecology and Obstetrics Clinic, Perinatology Department, İstanbul Kanuni Sultan Süleyman Training and Research Hospital, İstanbul, Turkey. e-mail: alged_1971@yahoo.com / Received: September 2, 2019; Accepted: September 30, 2019

Please cite this article as: Kıyak H, Atış Aydın A, Bolluk G, Canaz E, Ulaşkın Z, Gedikbaşı A. Anthropometric differences in the newborns with brachial plexus palsy, clavicle fracture in pregnancies without risk factor. Perinatal Journal 2019;27(2):105-112. doi:10.2399/prn.19.0272009 


\section{Introduction}

Despite many developments in obstetric diagnosis and prediction recently, shoulder dystocia has still been one of the most important issues that an obstetrician may face during labor. While it may occur by the obstruction of the anterior should of fetus by the symphis pubis during the move of fetus within pelvis, it also can be seen as the obstruction of posterior shoulder by sacral promontory. ${ }^{[1]}$ In cephalic vaginal deliveries, the incidence of shoulder dystocia may vary between $0.2 \%$ and $3 \% .{ }^{[2]}$ Also, brachial plexus palsy (BPP) develops in about $4 \%$ to $40 \%$ of these cases. ${ }^{[3,4]}$ It was also seen that the risk of clavicle fracture increases in some newborns during shoulder obstruction. ${ }^{[5,6]}$ However, clavicle fracture may occur spontaneously in many cases. ${ }^{[7,8]}$

The mechanism of BPP during shoulder dystocia has been considered as the case where the fetal head is moved away from the fetal body on axial plane through lateral traction by applying excessive force. However, a potential clavicle fracture that may occur in the meantime may be protective by increasing the cavity necessary for brachial plexus as well as the thoracic structure during a dystocic labor. A clavicle fracture may decrease the compression during the move of brachial plexus together with thorax by increasing the cavity between clavicle and 1 st rib actively. On the other hand, clavicle fracture itself is a sign of labor trauma and it indicates an increased risk for BPP. ${ }^{[9]}$ There is no consensus in the literature about the argument that the clavicle fracture in the presence of shoulder dystocia increases the severity of BPP. A retrospective study showed that a concomitant clavicle fracture supported the neurological recovery. ${ }^{[10]}$ On the other hand, another study reported that clavicle fracture was neither protective for the brachial plexus injury nor helped for the prediction of the severity of the injury. ${ }^{[1]}$ However, by any means, the development of BPP is an unpredictable issue for obstetricians in terms of medicolegal problems and the debates have been maintained within the scope of the interaction of intrinsic and iatrogenic forces on nerve damage. ${ }^{[12]}$

Many risk factors such as fetal macrosomia, maternal diabetes, advanced maternal age, maternal obesity and excessive weight gain during pregnancy, presence of polyhydramnios, history of shoulder dystocia, abnormal progress and dysfunction in labor, labor augmentation, and the need for operative vaginal labor. ${ }^{[1-15]}$ However, some anthropometric studies on the newborns show that there may be some differences in the newborns undergoing shoulder dystocia. ${ }^{[16-20]}$

Our aim in this study is to present newborn characteristics in complications such as BPP and clavicle, shoulder and humerus fractures with or without shoulder dystocia in our clinic and to make high suspicion and prediction for a potential shoulder dystocia and its complications. In order to achieve this purpose, we aimed to study with a group which was cleared of shoulder dystocia and its potential complications during pregnancy period as much as possible.

\section{Methods}

The shoulder dystocia is defined subjectively in many settings. In our clinic, the case when it takes more than 60 seconds after head is delivered and seen in the perineum and/or that it is necessary to perform an additional maneuver (such as McRoberts, suprapubic pressure, rotation maneuvers or knee-elbow position) if the shoulders have not been delivered yet is defined as shoulder dystocia. ${ }^{[2]}$ On the other hand, any complication may not be seen which can be detected definitely according to the examination findings of newborns in the cases with labor dystocia. In fact, the opposite also applies where complications may develop without shoulder dystocia or without noticing the presence of shoulder dystocia. ${ }^{[20-22]}$ Brachial plexus injury is the decreased movement in the upper extremity on relevant side compared to the other active upper extremity depending on the trauma and paresis of relevant nerve structure. ${ }^{[1]}$ The diagnosis of open or closed clavicle fracture or arm/humerus fracture is established by the $\mathrm{x}$-ray imaging together with the newborn examination.

The cases with dystocia or hypoxic ischemic encephalopathy associated with difficult labor were not included in our study. The exclusion criteria of our study were the establishment of the diagnosis of gestational diabetes mellitus (GDM) during antepartum period on the basis of OGTT during pregnancy, maternal body mass index (BMI) being over $30 \mathrm{~kg} / \mathrm{m}^{2}$ at labor, presence of the history of shoulder dystocia in multiparous women, deliveries before 37 weeks of gestation within intrapartum period, pregnant women who underwent induction or epidural anesthesia for the labor, and instrumental vaginal delivery which increase the risk of shoulder dystocia. Measuring estimated birth weight above $4500 \mathrm{~g}$ together with duplicated measure- 
ments in our hospital is an indication of cesarean section. Therefore, the fetuses whose estimated birth weights were calculated above $4500 \mathrm{~g}$ before birth and born with the birth weight above $4500 \mathrm{~g}$ were excluded from the study; however, the newborns with estimated birth weights below $4500 \mathrm{~g}$ and born with the birth weight above $4500 \mathrm{~g}$ were included in the study.

The newborns which had the complications of clavicle fracture, brachial plexus palsy/injury and shoulder/ humerus fracture and born according to the hospital database were determined between January 2013 and June 2019 and the study group was established by excluding non-matching cases according to their relevant anteand intrapartum characteristics. As the control group, the pregnant women in the study group were matched one by one with data of the newborns which had same obstetric and demographic characteristics, same weights and genders but did not undergo labor trauma. After excluding the prenatal factors associated with pregnancy which may lead to dystocic labor (fetal macrosomia, maternal diabetes, maternal obesity and excessive weight gain during pregnancy, history of shoulder dystocia, labor induction, epidural anesthesia), second stage of labor, newborn's sex, newborn weight, Apgar scores and anthropometric measurements of newborns for head and thorax circumferences were compared together with the maternal demographic data.

In this study, the statistical analyses were performed by NCSS (Number Cruncher Statistical System) 2007 Statistical Software (Kaysville, UT, USA). The descriptive statistical methods (mean, standard deviation, median, interquartile range, frequency and percentage distributions), Shapiro-Wilk normality test for the distribution of variables, one-way variance analysis for the comparisons of variables showing normal distribution, independent $t$ test for the comparison of two samples, Kruskal-Wallis test for the comparisons among groups not showing normal distribution, Mann-Whitney $U$ test for the comparison of two samples, and chi square test for the comparisons of the qualitative data were used for the analyses of the data. In the differential diagnosis of brachial plexus injury, prediction point was calculated for the variables of head circumference, thorax circumference and the ratio of thorax circumference/head circumference by using the values of ROC AUC, sensitivity, specificity, positive predictive value, negative predictive value and LR (+). The significance level of the results was considered $\mathrm{p}<0.05$.

\section{Results}

A total of 185 newborn complications with the necessary characteristics were observed between January 2013 and June 2019. Of them, 149 were classified as clavicle fracture, 8 as shoulder and humerus fracture, and 28 as brachial plexus palsy. Relevant maternal data, the duration of the 2nd stage of labor, presence of shoulder dystocia, Apgar scores and the association between newborn heights and weights for the study group and the control group are shown in Table $\mathbf{1}$. Accordingly, it was seen that the 2nd stage of labor was significantly longer in the cases which underwent the birth complication $(\mathrm{p}=0.01 ; 22.41 \pm 6.98$ minutes vs. $24.23 \pm 6.43$ minutes). Similarly, shoulder dystocia was more frequent in the study group which had complications ( $\mathrm{p}=0.0001 ; 32.97 \%$ vs. $2.7 \%$ ). In the study groups, 1-minute and 5-minute Apgar scores were significantly lower $(\mathrm{p}=0.0001$ for 1 -minute Apgar score and $\mathrm{p}=0.005$ for 5 -minute Apgar score).

No difference was observed between two groups in terms of birth weights due to the matching performed (Table 2). However, when newborn measurements were evaluated, it was seen that head and thorax circumferences were significantly higher in the complicated study group. In the mechanism of BPP built above, thorax and head circumferences were proportioned since the fetal head was moved away from the fetal body on axial plane through lateral traction by applying excessive force (Fig. 1). ${ }^{[9,23]}$ The ROC analysis of thorax circumference / head circumference ratio was significant, and it was seen that shoulder dystocia and the complications could be predicted in case that the ratio is higher than 0.97 ( $\mathrm{AUC}=0.903$; sensitivity $77.84 \%$, specificity $89.73 \%$, PPV $88.3 \%$, NPV $80.2 \%$, LR 7.58).

When the cases with clavicle fracture, shoulder/ humerus fracture and brachial plexus palsy/injury in which the complications were observed in the study group were evaluated separately in terms of demographic and anthropometric data, it was seen that the association of shoulder dystocia was higher in brachial plexus cases (Table 3) ( $\mathrm{p}=0.025$; association with brachial plexus: $53.57 \%$ ). It was found that the complications increased significantly in cases above $4000 \mathrm{~g}$ but below $4500 \mathrm{~g}(\mathrm{p}=0.029)$. No difference was observed in terms of the other parameters. 
Table 1. Maternal data, labor stage and newborn data.

\begin{tabular}{|c|c|c|c|c|}
\hline & & $\begin{array}{c}\text { Control group } \\
n=185\end{array}$ & $\begin{array}{c}\text { Study group } \\
\mathrm{n}=185\end{array}$ & $\mathbf{p}$ \\
\hline Gravida & $\begin{array}{l}\text { Mean } \pm S D \\
\text { Median (IQR) }\end{array}$ & $\begin{array}{c}2.46 \pm 1.49 \\
2(1-3)\end{array}$ & $\begin{array}{c}2.44 \pm 1.43 \\
2(1-3)\end{array}$ & $0.936^{*}$ \\
\hline Parity & $\begin{array}{l}\text { Mean } \pm S D \\
\text { Medyan (IQR) }\end{array}$ & $\begin{array}{c}1.03 \pm 1.1 \\
1(0-2) \\
\end{array}$ & $\begin{array}{c}1.01 \pm 1.08 \\
1(0-2)\end{array}$ & $0.948 *$ \\
\hline Maternal age (year) & Mean \pm SD & $26.85 \pm 5.81$ & $26.66 \pm 5.66$ & $0.751^{\dagger}$ \\
\hline BMI $\left(\mathrm{kg} / \mathrm{m}^{2}\right)$ & Mean \pm SD & $27.32 \pm 3.67$ & $27.26 \pm 3.29$ & $0.869^{\dagger}$ \\
\hline 2nd stage of labor (min) & Mean \pm SD & $22.41 \pm 6.98$ & $24.23 \pm 6.43$ & $0.01^{+}$ \\
\hline Shoulder dystocia & $\begin{array}{l}\text { Not available } \\
\text { Available }\end{array}$ & $\begin{array}{c}180(97.30 \%) \\
5(2.70 \%)\end{array}$ & $\begin{array}{c}124(67.03 \%) \\
61(32.97 \%)\end{array}$ & $0.0001^{\ddagger}$ \\
\hline Sex & $\begin{array}{l}\text { Male } \\
\text { Female }\end{array}$ & $\begin{array}{c}107(57.84 \%) \\
78(42.16 \%) \\
\end{array}$ & $\begin{array}{l}95(51.35 \%) \\
90(48.65 \%)\end{array}$ & $0.210^{\ddagger}$ \\
\hline 1-minute Apgar score & Mean \pm SD & $8.2 \pm 0.9$ & $7.69 \pm 1.4$ & $0.0001^{\dagger}$ \\
\hline 5-minute Apgar score & Mean \pm SD & $9.4 \pm 0.78$ & $9.15 \pm 0.94$ & $0.005^{+}$ \\
\hline Newborn height (cm) & Mean \pm SD & $50.96 \pm 1.53$ & $50.94 \pm 2.25$ & $0.949^{+}$ \\
\hline Newborn's birth weight (g) & Mean \pm SD & $3768.11 \pm 415.36$ & $3772.33 \pm 408.78$ & $0.922^{+}$ \\
\hline
\end{tabular}

*Mann-Whitney $\mathrm{U}$ test; ' ${ }^{\dagger}$ ndependent $\mathrm{t}$ test; ${ }^{\ddagger}$ Chi square test.

\section{Discussion}

Our study, which analyzes relevant data after the establishment of the clinic, retrospectively evaluates anthropometric measurements of the newborns with clavicle fracture, shoulder/humerus fracture and brachial plexus pals/injury which can be seen together with shoulder dystocia in terms of obstetrics. In 1982, Modanlou et al. ${ }^{[23]}$ published some anthropometric data of the newborns with and without shoulder dystocia and reported that shoulder circumference was higher in the cases with shoulder dystocia and the ratios of shoulder circumference/head circumference were also high in these cases. In the same study, the authors reported that anthropometric measurements were more explicit in the newborns of dia- betic women. Even macrosomia and the presence of diabetic mothers-newborns predicts only $55 \%$ of the shoulder dystocia cases, the data that may contribute to the prediction of birth complications which may be identified in this way have importance. ${ }^{[24]}$ Except these two risk factors, the studies showed that different additional antepartum and intrapartum factors such as maternal obesity and excessive weight gain during pregnancy, history of shoulder dystocia, abnormal progress of labor and dysfunction, and the need of operative vaginal labor may also contribute. ${ }^{[13]}$ By excluding all these factors, we conducted our study through newborns' anthropometric data and shoulder dystocia physiopathology, and from this point of view, we tried to present prediction hypothesis.

Table 2. Correlation between anthropometric measurements and weights.

\begin{tabular}{|c|c|c|c|c|}
\hline & & $\begin{array}{l}\text { Control group } \\
\qquad n=185\end{array}$ & $\begin{array}{l}\text { Study group } \\
\qquad n=185\end{array}$ & $\mathbf{p}$ \\
\hline Birth weight (g) & $\begin{array}{l}<4000 \\
>4000\end{array}$ & $\begin{array}{c}135(72.97 \%) \\
50(27.03 \%)\end{array}$ & $\begin{array}{c}131(70.81 \%) \\
54(29.19 \%)\end{array}$ & $0.644 *$ \\
\hline Birth weight (g) & $\begin{array}{l}<4500 \\
>4500\end{array}$ & $\begin{array}{c}174(94.05 \%) \\
11(5.95 \%) \\
\end{array}$ & $\begin{array}{c}176(95.14 \%) \\
9(4.86 \%)\end{array}$ & $0.646^{*}$ \\
\hline Head circumference $(\mathrm{cm})$ & Ort \pm SS & $35.53 \pm 1.19$ & $35.92 \pm 1.51$ & $0.006^{+}$ \\
\hline Thorax circumference $(\mathrm{cm})$ & Ort \pm SS & $33.22 \pm 1.35$ & $34.72 \pm 1.48$ & $0.0001^{\dagger}$ \\
\hline The ratio of thorax circumference / head circumference & Ort $\pm S S$ & $0.93 \pm 0.03$ & $0.98 \pm 0.03$ & $0.0001^{\dagger}$ \\
\hline
\end{tabular}

${ }^{*}$ Chi square test; ${ }^{\dagger}$ Independent $t$ test. 
Consistence with the literature, we saw in our study that the 2nd stage of labor prolonged in the complicated cases. ${ }^{[1,24,25]}$ Hypothetically and in accordance with the definition of the shoulder dystocia, this prolongation may be associated with the prolonged delivery of fetal shoulders. However, as seen in our study, the prolongation of the 2nd stage of labor may occur since head and thorax circumferences are higher and due to the passage of a larger object through the vagina and thus the frictional resistance although the weights of complicated patient group and control group are similar. Although shoulder dystocia is not present in all complicated cases, there was a significant association in the complicated patients and particularly in the BPP sub-group in our study. The functional recovery within 6 months after BPP is related to the level of current injury; while the recovery rate after the injuries of higher levels such as C5-C6 and C5-C7 is 64\%, the recovery rate for paresis in lower levels such as C5-T11 decreases to $14 \%$. $^{[1,2]}$ While the same resources point out the association of brachial plexus and shoulder dystocia, fracture complications such as clavicle fracture increases with the presence of shoulder dystocia, but they may occur without having any labor issue. ${ }^{[5-8]}$

While there are different publications on biometric measurements in the literature for the prenatal prediction of shoulder dystocia, ${ }^{[16-18,26-33]}$ most of them focus on the prediction associated with the difference between head and abdominal circumferences with shoulder dystocia in antenatal follow-ups and their relevant calculations. Unfortunately, these studies concluded that the dystocia cannot be predicted by antenatal measurements. On the other hand, only one study evaluated the correlation between the measurement of antenatal shoulder (bisacromial) diameter and macrosomia. ${ }^{[20]}$ In this study, Youssef et al. developed the formula of transthoracic diameter $+(2 \times$ forearm length $)$ and measured the bisacromial diameter indirectly, and they reported macrosomia prediction as $88.4 \%$ and sensitivity as $96.4 \%$ for a threshold value of $15.4 \mathrm{~cm}$. However, this study does not have any data for shoulder dystocia. Similarly, in our literature review, we found only a limited number of data in the literature for shoulder dystocia and newborns' shoulder diameter. ${ }^{[19,23]}$ These data showed that shoulder circumference measurement in newborns after birth were explicit in dystocic labors. The difficulties in the intrauterine process are the two ends of the shoulders showing variation which do not

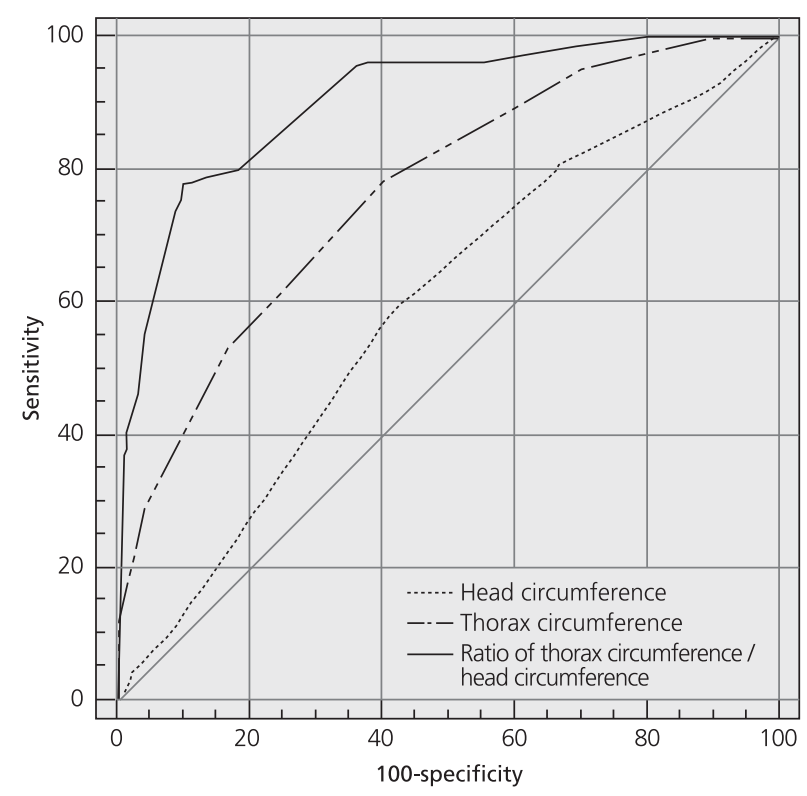

\begin{tabular}{lccc} 
& AUC & SE & $95 \% \mathrm{Cl}$ \\
\hline Head circumference $(\mathrm{cm})$ & 0.590 & 0.030 & $0.538-0.641$ \\
Thorax circumference $(\mathrm{cm})$ & 0.766 & 0.025 & $0.719-0.808$ \\
$\begin{array}{l}\text { The ratio of thorax circumference / } \\
\text { head circumference }\end{array}$ & 0.903 & 0.016 & $0.868-0.931$ \\
\hline
\end{tabular}

\begin{tabular}{llllllll} 
& \multicolumn{1}{c}{ Cut-off } & Sensitivity & Specificity & PPV & NPV & LR (+) \\
\hline Head circumference $(\mathrm{cm})$ & $>35$ & 58.38 & 58.38 & 58.4 & 58.6 & 1.40 \\
Thorax circumference $(\mathrm{cm})$ & $>33$ & 78.38 & 59.46 & 65.9 & 73.3 & 1.93 \\
$\begin{array}{l}\text { The ratio of thorax } \\
\text { circumference / head } \\
\text { circumference }\end{array}$ & $>0.97$ & 77.84 & 89.73 & 88.3 & 80.2 & 7.58 \\
\hline
\end{tabular}

Fig. 1. The anthropometric measurement and the ROC curve analysis of the rates.

locate on an anatomic position in the same plane, and being unable to evaluate them in the same plane within the birth canal in association with fetal and shoulder movements which are a part of labor.

Similar to our study, we found a limited number of data in the literature evaluating shoulder dystocia and the measurement of thorax circumference. ${ }^{[1,23,34-36]}$ These studies, similar to our study, compared the measurements and differences of head circumference and thorax circumference of the newborns having postnatal complications, and highlighted that the measurement of the thorax circumference was statistically significant. In one of these studies, Li et al.$^{[36]}$ retrospectively evaluated the antenatal 
Table 3. Newborn data together with the correlation of the complications with shoulder dystocia.

\begin{tabular}{|c|c|c|c|c|c|}
\hline & & $\begin{array}{c}\text { Clavicle fracture } \\
n=149\end{array}$ & $\begin{array}{l}\text { Shoulder and arm fracture } \\
\qquad n=8\end{array}$ & $\begin{array}{l}\text { Brachial plexus palsy } \\
\qquad n=28\end{array}$ & $\mathbf{p}$ \\
\hline Shoulder dystocia & $\begin{array}{l}\text { Not available } \\
\text { Available }\end{array}$ & $\begin{array}{c}104(69.80 \%) \\
45(30.20 \%)\end{array}$ & $\begin{array}{l}7(87.50 \%) \\
1(12.50 \%)\end{array}$ & $\begin{array}{l}13(46.43 \%) \\
15(53.57 \%)\end{array}$ & $0.025^{*}$ \\
\hline Gravida & $\begin{array}{l}\text { Mean } \pm \text { SD } \\
\text { Median (IQR) }\end{array}$ & $\begin{array}{l}2.46 \pm 1.39 \\
2(1-3)\end{array}$ & $\begin{array}{l}2.5 \pm 1.69 \\
2(1-4.5)\end{array}$ & $\begin{array}{c}2.32 \pm 1.61 \\
2(1-3)\end{array}$ & $0.886^{+}$ \\
\hline Parity & $\begin{array}{l}\text { Mean } \pm \text { SD } \\
\text { Median (IQR) }\end{array}$ & $\begin{array}{l}1.03 \pm 1.04 \\
1(0-2)\end{array}$ & $\begin{array}{l}1.13 \pm 1.46 \\
0.5(0-2)\end{array}$ & $\begin{array}{l}0.86 \pm 1.21 \\
0(0-1.75)\end{array}$ & $0.698^{+}$ \\
\hline $\mathrm{BMI}\left(\mathrm{kg} / \mathrm{m}^{2}\right)$ & & $27.23 \pm 3.32$ & $27.79 \pm 3.13$ & $27.26 \pm 3.31$ & $0.899 \neq$ \\
\hline 2nd stage of labor (min) & & $24.18 \pm 6.62$ & $24.25 \pm 5.6$ & $24.46 \pm 5.79$ & $0.978^{\neq}$ \\
\hline Maternal age (year) & & $27.02 \pm 5.71$ & $24.13 \pm 4.88$ & $25.5 \pm 5.39$ & 0.184 \\
\hline Sex & $\begin{array}{l}\text { Male } \\
\text { Female }\end{array}$ & $\begin{array}{l}81(54.36 \%) \\
68(45.64 \%)\end{array}$ & $\begin{array}{l}5(62.50 \%) \\
3(37.50 \%) \\
\end{array}$ & $\begin{array}{c}9(32.14 \%) \\
19(67.86 \%)\end{array}$ & $0.079 *$ \\
\hline Height $(\mathrm{cm})$ & & $50.99 \pm 2.38$ & $50.88 \pm 0.99$ & $50.71 \pm 1.8$ & $0.836^{\ddagger}$ \\
\hline Weight (g) & & $3750.98 \pm 394.25$ & $3741.25 \pm 417.9$ & $3894.82 \pm 472.36$ & $0.228^{\ddagger}$ \\
\hline Weight (g) & $\begin{array}{l}\leq 4000 \\
>4000\end{array}$ & $\begin{array}{c}112(75.17 \%) \\
37(24.83 \%)\end{array}$ & $\begin{array}{l}4(50.00 \%) \\
4(50.00 \%)\end{array}$ & $\begin{array}{l}15(53.57 \%) \\
13(46.43 \%)\end{array}$ & $0.029 *$ \\
\hline Weight (g) & $\begin{array}{l}\leq 4500 \\
>4500\end{array}$ & $\begin{array}{c}143(95.97 \%) \\
6(4.03 \%)\end{array}$ & $\begin{array}{c}8(100.00 \%) \\
0(0.00 \%)\end{array}$ & $\begin{array}{l}25(89.29 \%) \\
3(10.71 \%)\end{array}$ & $0.259 *$ \\
\hline Head circumference $(\mathrm{cm})$ & & $35.5 \pm 1.18$ & $35.88 \pm 1.55$ & $35.57 \pm 1.17$ & $0.680^{\ddagger}$ \\
\hline Thorax circumference $(\mathrm{cm})$ & & $34.67 \pm 1.43$ & $34.88 \pm 1.64$ & $34.96 \pm 1.71$ & $0.604^{\ddagger}$ \\
\hline $\begin{array}{l}\text { The ratio of thorax circumference / } \\
\text { head circumference }\end{array}$ & & $0.98 \pm 0.03$ & $0.97 \pm 0.04$ & $0.98 \pm 0.03$ & $0.486^{\ddagger}$ \\
\hline 1-minute Apgar score & & $7.74 \pm 1.28$ & $7.88 \pm 1.13$ & $7.36 \pm 1.97$ & $0.378^{\neq}$ \\
\hline 5-minute Apgar score & & $9.19 \pm 0.83$ & $9 \pm 0.76$ & $8.93 \pm 1.41$ & $0.350^{\ddagger}$ \\
\hline
\end{tabular}

${ }^{*}$ Chi square test; ${ }^{\dagger}$ Kruskal-Wallis test; ${ }^{\ddagger}$ One-way variance analysis.

data of the newborns undergoing shoulder dystocia and birth complications similar to our study, and reported that the measurement of postnatal thorax circumference and the ratio of newborn thorax circumference/head circumference were statistically significant. In our study, we found that both head circumference and thorax circumference were significantly higher in the study group undergoing complication, and wanted to highlight that these postnatal data may be statistically significant in the prediction indirectly. While trying to highlight the difficulty of measuring the bisacromial diameter in women during labor, we hypothesized that it may be possible to measure the thorax diameter on the plane of four-chamber cavity in rather more stable conditions and ultrasound cross-section. After we observed that the ratios of thorax circumference/head circumference of newborns in particular were statistically significant, and that the complications associated with birth trauma were present particularly in the newborns with a weight above $4000 \mathrm{~g}$, we initiated a prospective study in our clinic for that purpose in order to reflect these measurements into antenatal assessments and to evaluate the hypothesis.

\section{Conclusion}

The antenatal studies for the prediction of birth complications that may develop during labor with or without shoulder dystocia are insufficient. The studies performed so far have mainly focused on the determination of the risk groups, and they are not completely helpful for the prediction of conditions that may develop during labor. Additional data are required to evaluate both birth channel and the fetus inside completely during labor. The newborns with the same weight may have different physical characteristics, and therefore these differences should be taken into consideration. While fetal cranial structures within the birth canal are relatively more protected in the calvarium, the shoulders and the relevant extensions are vulnerable to the trauma as more labile and moving organ parts. Therefore, we have seen in our hypothesis that neonatal anthropometric data and the 
measurements of head circumference together with the thorax circumference in particular were significant in the complicated cases. In order to make a prediction, bisacromial diameter and thorax circumference measurements as well as fetal head measurements may be helpful during antenatal period and labor in particular.

Conflicts of Interest: No conflicts declared.

\section{References}

1. Committee on Practice Bulletins--Obstetrics. Practice Bulletin Number No 178: Shoulder dystocia. Obstet Gynecol 2017;129:e123-e133.

2. Gherman RB, Chauhan S, Ouzounian JG, Lerner H, Gonik B, Goodwin TM. Shoulder dystocia: the unpreventable obstetric emergency with empiric management guidelines. Am J Obstet Gynecol 2006;195:657-72.

3. Kees S, Margalit V, Schiff E, Mashiach S, Carp HJ. Features of shoulder dystocia in a busy obstetric unit. J Reprod Med 2001;46:583-8.

4. Bofill JA, Rust OA, Devidas M, Roberts WE, Morrison JC, Martin JN Jr. Shoulder dystocia and operative vaginal delivery. J Matern Fetal Med 1997;6:220-4.

5. Lopez E, de Courtivron B, Saliba E. Neonatal complications related to shoulder dystocia. [Article in French] J Gynecol Obstet Biol Reprod (Paris) 2015;44:1294-1302.

6. Karahanoglu E, Kasapoglu T, Ozdemirci S, Fadıloglu E, Akyol A, Demirdag E, et al. Risk factors for clavicle fracture concurrent with brachial plexus injury. Arch Gynecol Obstet 2016;293:783-7.

7. Beall MH, Ross MG. Clavicle fracture in labor: risk factors and associated morbidities. J Perinatol 2001;21:513-5.

8. Ozdener T, Engin-Ustun Y, Aktulay A, Turkcapar F, Oguz S, Yapar Eyi EG, et al. Clavicular fracture: its incidence and predisposing factors in term uncomplicated pregnancy. Eur Rev Med Pharmacol Sci 2013;17:1269-72.

9. Doumouchtsis SK, Arulkumaran S. Are all brachial plexus injuries caused by shoulder dystocia? Obstet Gynecol Surv 2009;64:615-23.

10. Wall LB, Mills JK, Leveno K, Jackson G, Wheeler LC, Oishi SN, et al. Incidence and prognosis of neonatal brachial plexus palsy with and without clavicle fractures. Obstet Gynecol 2014;123:1288-93.

11. Leshikar HB, Bauer AS, Lightdale-Miric N, Molitor F, Waters PM; TOBI Study Group. Clavicle fracture is not predictive of the need for microsurgery in brachial plexus birth palsy. J Pediatr Orthop 2018;38:128-32.

12. Gonik B, Zhang N, Grimm MJ. Prediction of brachial plexus stretching during shoulder dystocia using a computer simulation model. Am J Obstet Gynecol 2003;189:1168-72.

13. Mehta SH, Sokol RJ. Shoulder dystocia: risk factors, predictability, and preventability. Semin Perinatol 2014;38:18993.
14. Erdoğan K, Yapar Eyi EG. Comparison of high and low doses of oxytocin protocols in multiparous pregnant women in terms of labor durations and fetal-maternal complications. Perinatal Journal 2017;25:11-8.

15. Akyol A, Talay H, Gedikbaşı A, Ark C, Ülker V, Özdemir Ç. The factors effective on the macrosomic deliveries of non-diabetic pregnant women. Perinatal Journal 2014;22: 83-7.

16. Secher AL, Bytoft B, Tabor A, Damm P, Mathiesen ER. Fetal sonographic characteristics associated with shoulder dystocia in pregnancies of women with type 1 diabetes. Acta Obstet Gynecol Scand 2015;94:1105-11.

17. Larson A, Mandelbaum DE. Association of head circumference and shoulder dystocia in macrosomic neonates. Matern Child Health J 2013;17:501-4.

18. Burkhardt T, Schmidt M, Kurmanavicius J, Zimmermann R, Schäffer L. Evaluation of fetal anthropometric measures to predict the risk for shoulder dystocia. Ultrasound Obstet Gynecol 2014;43:77-82.

19. Winn HN, Holcomb W, Shumway JB, al-Malt A, Amon E, Hobbins JC. The neonatal bisacromial diameter: a prenatal sonographic evaluation. J Perinat Med 1997;25:484-7.

20. Youssef AEA, Amin AF, Khalaf M, Khalaf MS, Ali MK, Abbas AM. Fetal biacromial diameter as a new ultrasound measure for prediction of macrosomia in term pregnancy: a prospective observational study. J Matern Fetal Neonatal Med 2019;32: 2674-9.

21. Spong CY, Beall M, Rodriques D, Ross MG. An objective definition of shoulder dystocia: prolonged head-to-body delivery intervals and/or the use of ancillary obstetric maneuvers. Obstet Gynecol 1995;86:433-6.

22. Miller LA. Shoulder dystocia: planning for the unpredictable. J Perinat Neonatal Nurs 2014;28:256-8.

23. Modanlou HD, Komatsu G, Dorchester W, Freeman RK, Bosu SK. Large-for-gestational-age neonates: anthropometric reasons for shoulder dystocia. Obstet Gynecol 1982;60: $417-23$.

24. Acker DB, Sachs BP, Friedman EA. Risk factors for shoulder dystocia. Obstet Gynecol 1985;66:762-8.

25. Anderson JE. Complications of labor and delivery: shoulder dystocia. Prim Care 2012;39:135-44.

26. Cohen B, Penning S, Major C, Ansley D, Porto M, Garite T. Sonographic prediction of shoulder dystocia in infants of diabetic mothers. Obstet Gynecol 1996;88:10-3.

27. Cohen BF, Penning S, Ansley D, Porto M, Garite T. The incidence and severity of shoulder dystocia correlates with a sonographic measurement of asymmetry in patients with diabetes. Am J Perinatol 1999;16:197-201.

28. Rajan PV, Chung JH, Porto M, Wing DA. Correlation of increased fetal asymmetry with shoulder dystocia in the nondiabetic woman with suspected macrosomia. J Reprod Med 2009;54:478-82.

29. Miller RS, Devine PC, Johnson EB. Sonographic fetal asymmetry predicts shoulder dystocia. J Ultrasound Med 2007;26: 1523-8. 
30. Abramowicz JS, Robischon K, Cox C. Incorporating sonographic cheek-to-cheek diameter, biparietal diameter and abdominal circumference improves weight estimation in the macrosomic fetus. Ultrasound Obstet Gynecol 1997;9:40913.

31. Parantainen J, Palomäki O, Talola N, Uotila J. Clinical and sonographic risk factors and complications of shoulder dystocia - a case-control study with parity and gestational age matched controls. Eur J Obstet Gynecol Reprod Biol 2014; 177:110-4.

32. Athukorala C, Crowther CA, Willson K; Austrailian Carbohydrate Intolerance Study in Pregnant Women (ACHOIS) Trial Group. Women with gestational diabetes mellitus in the ACHOIS trial: risk factors for shoulder dystocia. Aust N Z J Obstet Gynaecol 2007;47:37-41.
33. Chauhan SP, Lynn NN, Sanderson M, Humphries J, Cole JH, Scardo JA. A scoring system for detection of macrosomia and prediction of shoulder dystocia: a disappointment. J Matern Fetal Neonatal Med 2006;19:699-705.

34. Hitschold T, Grewe J. Shoulder dystocia - risk factors and indicators. A retrospective analysis within an obstetric collective of 14,913 deliveries. [Article in German] Z Geburtshilfe Neonatol 2008;212:211-6.

35. Kozovski I, Popova A, Protopopov F, Petkova U, Cherneva S. Fetal shoulder girdle dystocia during labor. [Article in Bulgarian] Akush Ginekol (Sofiia) 1990;29:18-22.

36. Li N, Li Q, Chang L, Liu C. Risk factors and clinical prediction of shoulder dystocia in non-macrosomia. [Article in Chinese] Zhonghua Fu Chan Ke Za Zhi 2015;50:17-21.

Bu makalenin kullanım izni Creative Commons Attribution-NoCommercial-NoDerivs 3.0 Unported (CC BY-NC-ND3.0) lisansı aracılı̆̆ılyla bedelsiz sunulmaktadir. / This work is licensed under the Creative Commons Attribution-NonCommercial-NoDerivs 3.0 Unported (CC BY-NC-ND3.0) License. To view a copy of this license, visit http://creativecommons.org/licenses/by-nc-nd/3.0/ or send a letter to Creative Commons, PO Box 1866 , Mountain View, CA 94042, USA. 